\title{
JURNAL ILMIAH HUBUNGAN POLA ASUH IBU DENGAN PERILAKU SULIT MAKAN PADA ANAK USIA PRASEKOLAH
}

\author{
Devi Listiana ${ }^{1}$, Vellyza Colin ${ }^{2}$, Lidya Syndita ${ }^{3}$ \\ Program Studi Ilmu Keperawatan STIKES Tri Mandiri Sakti Bengkulu ${ }^{1,2,3}$ \\ devilistiana01@gmail.com ${ }^{1}$
}

\begin{abstract}
ABSTRAK
Perilaku sulit makan dapat memicu masalah gizi pada anak, di mana anak yang sulit makan cenderung mengalami gizi kurang hingga gizi buruk. Penelitian ini bertujuan untuk mengetahui hubungan antara pola asuh ibu dengan perilaku sulit makan pada anak usia prasekolah di RW. 002 Kelurahan Sidomulyo Kota Bengkulu. Metode yang digunakan dalam penelitian ini ialah metode korelasional. Populasi dalam penelitian ini adalah seluruh Ibu yang memiliki anak pada usia Prasekolah. Teknik pengambilan sampel yang digunakan dalam penelitian ini adalah accidental sampling sebanyak 59 responden. Data yang digunakan adalah data primer dan data sekunder. Data dianalisis menggunakan analisis univariat dan analisis bivariat. Hasil penelitian didapatkan dari 59 responden terdapat $52(88,1 \%)$ responden dengan pola asuh baik, 49 orang responden $(83,1 \%)$ tidak mengalami perilaku sulit makan. Hasil analisis korelasi Product Moment Pearson didapat $\mathrm{p}$ value $=0,419$. Simpulan, tidak ada hubungan pola asuh Ibu dengan perilaku sulit makan anak pada anak usia prasekolah di RW. 002 Kelurahan Sidomulyo Kota Bengkulu. Tenaga kesehatan diharapkan dapat memberikan informasi dan masukan bagi ibu yang memiliki anak usia prasekolah tentang perilaku sulit makan untuk mencegah dan mengatasi perilaku sulit makan pada anak.
\end{abstract}

Kata kunci: Usia Prasekolah, Perilaku Sulit Makan, Pola Asuh Ibu

\section{ABSTRACT}

Difficulty eating behavior can lead to nutritional problems in children, where children who have difficulty eating tend to experience malnutrition to malnutrition. This study aims to determine the relationship between mother's upbringing and eating difficult behavior in preschool children in RW. 002 Kelurahan Sidomulyo Bengkulu City. The method used in this research is the correlational method. The population in this study were all mothers who have children at preschool age. The sampling technique used in this study was accidental sampling of 59 respondents. The data used are primary data and secondary data. Data were analyzed using univariate analysis and bivariate analysis. The results obtained from 59 respondents, there were $52(88.1 \%)$ respondents with good parenting, 49 respondents $(83.1 \%)$ did not experience difficult eating behavior. The results of the Pearson Product Moment correlation analysis obtained $p$ value $=0.419$. In conclusion, there is no relationship between mother's upbringing and eating difficult behavior among preschool children in RW. 002 Kelurahan Sidomulyo Bengkulu City. Health workers are expected to be able to provide information and input for mothers with preschool children about eating difficult behaviors to prevent and overcome eating difficult behavior in children.

Key words: Preschool Age, Difficult Eating Behavior, Mother's Parenting 


\section{PENDAHULUAN}

Menurut Soetjiningsih (2013) usia prasekolah adalah ketika anak mengalami perkembangan psikis menjadi lebih autonom, mandiri, serta dapat berinteraksi dengan lingkungan disekitarnya, juga lebih mengekspresikan emosi dalam dirinya. Ungkapan luapan emosi yang sering terjadi adalah menangis atau menjerit ketika anak tidak merasa nyaman. Pola makan anak dapat dipengaruhi oleh sifat perkembangan yang terbentuk. Hal tersebut yang dapat menyebabkan anak terkadang bersikap terlalu pemilih, seperti cenderung menyukai cemilan (makanan ringan) sehingga menjadi kenyang dan menolak makan ketika periode makan. Saat orangtua menyuapi makanan, biasanya anak juga rewel dan lebih sering memilih untuk bermain. Jika tidak segera diatasi, maka anak akan mengalami kesulitan makan.

Menurut Waugh (2010) angka kejadian masalah kesulitan makan di beberapa negara cukup tinggi. The Gateshead Millennium Baby Study telah melakukan penelitian pada tahun 2006 di Inggris menyebutkan $20 \%$ orang tua mengatakan anaknya mengalami masalah makan, anak hanya mau makan makanan tertentu dengan prevalensi tertinggi. Orang tua mengeluhkan anaknya sangat pemilih terhadap makanan sebanyak 19$50 \%$, sehingga lebih sering terjadi defisiensi zat gizi pada survei yang dilakukan di Amerika Serikat pada tahun 2004.

Kesulitan makan terjadi ketika anak tidak mau atau menolak untuk makan atau mengalami kesulitan dalam mengkonsumsi makanan atau minuman dengan jenis dan jumlah yang sesuai dengan usia. Menurut hasil penelitian yang dilakukan di Jakarta bahwa pada anak usia 4-6 tahun, didapatkan prevalensi kesulitan makan sebesar 33,6 $\%$, dan sebagian besar $(79,2 \%)$ telah berlangsung lebih dari 3 bulan (Judarwanto, 2011).
Prasetyo (2011) mengemukakan bahwa prevalensi kesulitan makan pada masa prasekolah sebesar $25 \%$. Usia prasekolah dari umur 4 sampai 6 tahun meningkat menjadi $33,6 \%$. Prevalensi kekurangan gizi pada anak di Indonesia mencapai angka 19,6\% (Riskesdas, 2013 dari Gizinet, 2014). Jika dibandingkan pada tahun 2010 dengan prevalensi sebesar $17,9 \%$, hal tersebut mengalami peningkatan yang cukup signifikan. Kementerian Kesehatan RI juga mengemukakan bahwa asupan gizi buruk masih sering terjadi di beberapa wilayah di Indonesia, seperti Bali $(11,4 \%)$, Yogyakarta $(10,0 \%)$, dan NTT $(33,6 \%)$ (Kemenkes RI, 2015).

Menurut hasil penelitian yang dilakukan oleh Program Lembaga Pangan Dunia (LPD) pada awal tahun 2008 mengatakan bahwa jumlah penderita gizi buruk dan rawan pangan di Indonesia mencapai angka 13 juta. Menurut data pemerintah RI bahwa penderita gizi buruk hingga tahun 2007 mencapai angka 4,1 juta, atau naik $3 x$ lipat dibanding jumlah penderita yang sama pada tahun 2005 yakni 1,67 juta jiwa (Saragih, 2011).

Hal penting yang harus diketahui oleh setiap orang tua adalah pemenuhan gizi pada anak usia prasekolah. Perlunya perhatian lebih dalam tentang tumbuh kembang pada usia balita berdasarkan fakta bahwa kurang gizi yang terjadi pada masa emas ini, bersifat tidak dapat pulih (irreversible). Berdasarkan data pada tahun 2007 menunjukkan bahwa 4 juta balita Indonesia kekurangan gizi, 700 ribu diantaranya mengalami gizi buruk. Sementara yang mendapat program makanan tambahan hanya 39 ribu anak. Status gizi ditinjau dari tinggi badan, sebanyak 25,8 persen anak balita Indonesia pendek.

Stunting (ukuran tubuh yang pendek) merupakan tanda kurang gizi yang berkepanjangan. Selanjutnya, kekurangan gizi dapat mempengaruhi perkembangan otak pada anak, yang 
tumbuh selama masa balita. Fase cepat pertumbuhan otak mulai berlangsung dari janin berusia 30 minggu sampai dengan bayi berusia 18 bulan (Khomsan, 2009).

Menurut Siswono (2011) masalah gizi terjadi terutama pada anak-anak merupakan masalah klasik Indonesia setiap tahunnya, jumlah anak yang terkena gizi kurang mengalami peningkatan. Tahun 2005 ditemukan 1,8 juta anak dengan status gizi yang buruk, dalam jangka waktu yang sangat singkat meningkat menjadi 2,3 juta pada tahun 2006 anak menderita gizi buruk. Sementara itu, 27\% anak di Indonesia diperkirakan mengalami gizi buruk, hingga Maret 2008.

Penelitian yang dilakukan oleh Hariani (2015) yang berjudul faktorfaktor yang berhubungan dengan kesulitan makan pada anak usia 3-5 tahun di TK Gowata Desa Taeng Kec. Pallangga Kab. Gowa. Dalam hasil penelitian ini didapatkan bahwa ada hubungan antara peran orang tua dengan kesulitan makan, lingkungan, jenis makanan, dan psikologis pada anak di TK Gowata Desa Taeng Kec. Pallangga Kab. Gowa.

Oleh karena itu diperlukan penelitian lebih mendalam mengenai pola asuh ibu dengan perilaku sulit makan pada anak usia prasekolah. Sehingga peneliti merasa penting untuk melakukan penelitian hubungan pola asuh ibu dengan perilaku sulit makan pada anak usia prasekolah di RW. 002 Kelurahan Sidomulyo Kota Bengkulu. Penelitian sebelumnya untuk melihat apakah faktorfaktor yang berhubungan dengan kesulitan makan pada anak usia 3-5 tahun. Dengan menggunakan uji statistik Chi-square, berbeda dengan penelitian ini data dianalisis menggunakan uji korelasi product moment pearson (؟).

Data dari Dinas Kesehatan Bengkulu masalah sekitar 18.000 anak prasekolah menderita perilaku sulit makan. Sebanyak 17.150 anak dengan gizi kurang dan 1.180 anak lainnya mendapat gizi buruk. Saat ini terdapat 280.000 anak di Bengkulu.

Data dari beberapa Ibu yang memiliki anak usia prasekolah di RW. 002 Kelurahan Sidomulyo Bengkulu pada tahun 2015 terdapat sekitar 78 anak, tahun 2016 terdapat sekitar 83 anak dan tahun 2017 terdapat sekitar 91 anak usia prasekolah berada pada gizi buruk (garis merah). Jadi, dapat disimpulkan bahwa ada peningkatan gizi buruk pada setiap tahunnya. Hal itu disebabkan karena ada beberapa anak usia pra sekolah yang menunjukkan berat badan kurang dikarenakan sulit makan. Beberapa anak memiliki masalah makan misalnya anak hanya mau makan makanan ringan, seperti snack, dan lain sebagainya.

Berdasarkan uraian diatas peneliti tertarik untuk mengetahui bagaimana pola asuh orang tua dan pola makan pada anak usia prasekolah di RW. 002 Kelurahan Sidomulyo Kota Bengkulu, adapun tujuan penelitian ini adalah untuk mengetahui hubungan antara pola asuh ibu dengan perilaku sulit makan pada anak usia prasekolah di RW. 002 Kelurahan Sidomulyo Kota Bengkulu.

\section{METODE PENELITIAN}

Penelitian dilakukan di RW. 002 Kelurahan Sidomulyo Kota Bengkulu pada bulan Agustus-September 2018. Metode yang digunakan dalam penelitian ini ialah metode korelasional karena penelitian ini disajikan dengan angkaangka. Populasi dalam penelitian ini adalah seluruh Ibu yang memiliki anak pada usia Prasekolah di RW. 002 Kelurahan Sidomulyo Kota Bengkulu.

Teknik pengambilan sampel yang digunakan dalam penelitian ini adalah Accidental Sampling dan diperoleh sebanyak 59 Ibu yang memiliki anak pada usia Prasekolah. Data yang digunakan adalah data primer dan data sekunder. Data dianalisis menggunakan analisis univariat dan bivariate dengan uji korelasi product moment pearson (؟). 
HASIL PENELITIAN

Analisis Univariat

Analisis ini dilakukan untuk menghasilkan deskripsi distribusi frekuensi variable independent (Pola Asuh Ibu) dan variable dependent (Perilaku sulit makan pada Anak usia prasekolah, yaitu usia 3 sampai dengan 5 tahun) pada Ibu yang memiliki anak pada usia Prasekolah di RW. 002 Kelurahan Sidomulyo Kota Bengkulu.

Dari Tabel 1 berikut ini dapat diketahui dari 59 orang ibu terdapat 52 orang $(88,1 \%)$ yang memiliki pola asuh baik dan 7 orang $(11,9 \%)$ degan pola asuh kurang baik.

Tabel 1.

Distribusi Frekuensi Pola Asuh Ibu pada Anak Usia Prasekolah

\begin{tabular}{clcc}
\hline No & Pola Asuh Ibu & Frekuensi & $\begin{array}{c}\text { Persentase } \\
(\%)\end{array}$ \\
\hline 1 & Baik & 52 & 88.1 \\
2 & Kurang Baik & 7 & 11.9 \\
\hline & Total & 59 & 100.0 \\
\hline
\end{tabular}

Tabel 2.

Distribusi Frekuensi Pola Asuh Ibu dan Perilaku Sulit Makan pada Anak Usia Prasekolah

\begin{tabular}{clcc}
\hline No & $\begin{array}{l}\text { Perilaku Sulit } \\
\text { Makan }\end{array}$ & Frekuensi & $\begin{array}{c}\text { Persentase } \\
(\%)\end{array}$ \\
\hline 1 & $\begin{array}{l}\text { Tidak } \\
\text { Mengalami }\end{array}$ & 49 & 83.1 \\
2 & $\begin{array}{l}\text { Mengalami } \\
\text { Total }\end{array}$ & 10 & 16.9 \\
\hline
\end{tabular}

Dari Tabel 2 diketahui dari 59 orang ibu terdapat 49 orang $(83,1 \%)$ tidak mengalami perilaku sulit makan dan 10 orang $(16,9 \%)$ mengalami perilaku sulit makan.

\section{Analisis Bivariat}

Analisis ini untuk mengetahui ada atau tidaknya hubungan pola asuh ibu dengan perilaku sulit makan pada anak usia prasekolah Berdasarkan hasil penelitian yang dilakukan, maka tabulasi antara variable independent dan dependen dapat dilihat pada table di bawah ini:
Tabel 3.

Correlations

\begin{tabular}{lcc}
\hline \multicolumn{1}{c}{ Variabel } & r & $P$ \\
\hline $\begin{array}{l}\text { Pola Asuh Ibu * } \\
\text { Perilaku Sulit Makan } \\
\text { pada Anak Usia }\end{array}$ & & \\
Prasekolah & 0,107 & 0,419 \\
\hline
\end{tabular}

Hasil analisis korelasi Product Moment Pearson didapat nilai $\mathrm{r}=0,107$ dengan sig. $(\mathrm{p})=0,419>0,05$ berarti tidak signifikan, maka Ho diterima dan $\mathrm{Ha}$ ditolak. Jadi, tidak ada hubungan pola asuh Ibu dengan perilaku sulit makan anak pada anak usia prasekolah di RW. 002 Kelurahan Sidomulyo Kota Bengkulu.

\section{PEMBAHASAN}

Hasil penelitian menunjukkan bahwa dari 59 sampel terdapat 52 $(88,1 \%)$ ibu yang memiliki pola asuh pada anak usia prasekolah baik. Berdasarkan hasil penelitian didapatkan bahwa sebagian besar anak diberikan kebebasan oleh Ibu agar dapat mengeksplorasi berbagai hal sesuai dengan kemampuan masing-masing anak untuk berkreasi sesuai dengan sensor batasan dan juga pengawasan dari Ibu yang baik.

Hasil penelitian ini didukung oleh Septiari (2012) bahawa ada beberapa macam pola asuh pada anak, diantaranya pola asuh otoritatif, pola asuh otoriter, dan juga pola asuh permisif. Pola asuh orang tua pada anak yang memberi kebebasan pada anak untuk berkreasi dan mengeksplorasi berbagai hal sesuai dengan kemampuan anak dengan sensor batasan dan pengawasan yang baik dari orangtua merupakan pola asuh otoritatif. Pola asuh tersebut merupakan pola asuh yang baik untuk dapat diaplikasikan bagi para orang tua kepada anak-anak mereka.

Mengingat anak adalah individu yang unik, dan bukan miniatur orang dewasa, sehingga setiap anak memiliki perbedaan perlakuan dan pola asuh, orangtua harus mengerti masing-masing 
karakter anaknya, sehingga anak mendapat pola asuh yang tepat sehingga anak akan lebih hidup bahagia, menyenangkan, kreatif, cerdas, percaya diri, terbuka pada orang tua, menghargai dan menghormati orangtuanya, tidak mudah stres dan juga depresi, berprestasi baik, disukai oleh lingkungan dan masyarakat (Padila, Andari, Harsismanto J. \& Andri, 2019).

Hasil penelitian ini sejalan dengan hasil penelitian yang dilakukan oleh Karaki, Kundre \& Karundeng (2016) yang meneliti tentang hubungan pola asuh ibu dengan perilaku sulit makan pada anak usia pra sekolah di didapatkan data dari 35 anak terdapat 20 anak $(57,1 \%)$ dengan pola asuh baik.

Hasil penelitian menunjukkan bahwa dari 59 sampel terdapat 49 $(83,1 \%)$ yang ibu tidak mengalami anak dengan perilaku sulit makan pada anak usia prasekolah. Dari hasil penelitian peneliti anak-anak tidak menolak untuk makan atau minum dengan jenis dan jumlah sesuai usia secara fisiologis (alamiah dan wajar), sehingga rata-rata ibu yang memiliki anak usia prasekolah tidak mengalami perilaku sulit makan.

Menurut Karaki, Kundre \& Karundeng (2016) faktor-faktor penyebab kesulitan makan pasti dipengaruhi oleh beberapa hal, antara lain proses makan yang terjadi mulai dari memasukkan makan di mulut, mengunyah, menelan dan juga termasuk faktor organik. Hal yanga sangat berperan dalam proses makan tersebut adalah kemampuan koordinasi pergerakan motorik kasar pada daerah sekitar mulut.

Gangguan makan disebabkan oleh berbagai kelainan atau penyakit pada organ-organ pencernaan yang pada akhirnya dapat menyebabkan gangguan pada sistem pencernaan. Gangguan pada sistem pencernaan tersebut dapat terjadi ketika anak mengalami sariawan, sakit tenggorokan atau adanya penyakit di organ pencernaan.
Hasil penelitian ini didukung juga oleh penelitian sebelumnya yang dilakukan oleh Hariani (2015) yang meneliti faktor-faktor yang Berhubungan dengan Kesulitan Makan pada Anak Usia 3-5 Tahun didapatkan hasil penelitian bahwa dari 53 anak terdapat $46(86,8 \%)$ anak tidak mengalami perilaku sulit makan pada anak usia pra sekolah. Hasil penelitian tersebut mengatakan bahwa faktor-faktor yang mempengaruhi perilaku sulit makan pada anak antara lain faktor lingkungan, jenis makanan, dan psikologis pada anak.

Hasil analisis menggunakan korelasi Product Moment Pearson menunjukkan tidak ada hubungan pola asuh Ibu dengan perilaku sulit makan anak pada anak usia prasekolah di RW. 002 Kelurahan Sidomulyo Kota Bengkulu.

Dari hasil penelitian didapatkan bahwa ada faktor lain yang mempengaruhi perilaku sulit makan pada anak usia pra sekolah yaitu faktor gangguan saluran pencernaan dan jenis makanan seperti nasi keras dan menu makanan yang tidak bervariasi, menjadi faktor utama yang mempengaruhi perilaku sulit makan anak usia pra sekolah pada penelitian ini. Dari hasil penelitian peneliti rata-rata ibu yang memiliki anak usia prasekolah mengalami perilaku sulit makan karena anak tidak dapat mengunyah ataupun menelan makanan yang disajikan. Gangguan yang dialami anak yaitu sariawan dan sakit tenggorokan (Zaviera, 2012).

Menurut hasil penelitian sebelumnya Karaki, Kundre \& Karundeng (2016) bahwa salah satu faktor yang menyebabkan anak mengalami kesulitan makan adalah jenis makanan pada anak karena anak usia prasekolah dikenal sebagai konsumen aktif, yang mulai dapat memilih jenis makanan yang ingin dimakan dan menolak terhadap jenis makanan baru. Perilaku sulit makan pada anak tersebut 
juga dipengaruhi oleh ketidaksukaan mereka terhadap jenis makanan tertentu.

Faktor penyebab terpenting dalam gangguan proses makan di mulut adalah gangguan pada sistem pencernaan. Apabila terdapat gangguan pada sistem pencernaan, maka peristiwa tersebut dapat mempengaruhi mekanisme kerja sistem saraf pusat (SSP), sehingga terjadi gangguan pada mekanisme kerja sistem saraf pusat (SSP). Gangguan pada mekanisme kerja sistem saraf pusat (SSP) tersebut dapat berupa gangguan pada neurofungsional dan juga neuroanatomis. Gangguan koordinasi motorik kasar pada mulut merupakan salah satu manifestasi klinis yang dapat terjadi.

Pada umumnya dapat mengakibatkan gangguan yang dapat mengakibatkan gangguan makan pada berbagai kelainan atau penyakit pada beberapa organ tersebut. Saat anak mengalami sariawan, sakit tenggorokan atau adanya penyakit di organ pencernaan, gangguan tersebut dapat terjadi (Zaviera, 2012).

Hasil penelitian ini tidak sejalan dengan hasil penelitian yang dilakukan Hariani (2015) sebelumnya yang menyebutkan bahwa ada hubungan antara jenis makanan dengan kesulitan makan pada anak usia 3-5 tahun di TK Gowata Desa Taeng Kec. Pallangga Kab. Gowa, di mana mayoritas anak akan merasa senang jika jenis makanan yang diberikan bervariasi, disajikan semenarik mungkin dan memiliki rasa yang enak.

Penelitian ini bertolak belakang juga dengan hasil penelitian yang dilakukan oleh Karaki, Kundre \& Karundeng (2016) yang dilakukan di Desa Palelon Kecamatan Modoinding Minahasa Selatan yang menyatakan bahwa ada hubungan pola asuh ibu dengan perilaku sulit makan pada anak usia prasekolah. Dari hasil penelitian tersebut pembentukan perilaku dan karakter anak sangatlah penting pola asuh orang tua yang baik karena anak seringkali meniru kebiasaan dan perilaku dari orang tua mereka baik ibu atau ayah mereka, termasuk menirukan kebiasaan makan ibu atau ayahnya. Oleh karena itu, tumbuh kembang anak terlebih kebiasaan makan sangat dipengaruhi oleh pola asuh orang tua, sehingga pola asuh yang tidak baik dari orang tua, baik ayah maupun ibu dapat menyebabkan seorang anak dapat mengalami perilaku sulit makan.

Menurut teori Zaviera (2012) ada beberapa faktor yang menyebabkan masalah kesulitan makan yaitu faktor organik, faktor nutrisi dan faktor psikologi.

Gangguan pada sistem pencernaan dan jenis makanan adalah merupakan salah satu faktor organik. Terjadi perubahan pada cara makan dari makanan bayi ke usia dewasa, ketepatan jenis dan jumlah takaran makanan sangat menentukan pemenuhan gizi merupakan faktor nutrisi yang penting. Kekeliruan pengelolaan orang tua dalam melakukan pengaturan pola makan pada anaknya merupakan faktor psikologi (kejiwaan).

Hasil penelitian menyimpulkan tidak ada hubungan pola asuh ibu dengan perilaku sulit makan pada anak usia prasekolah karena lebih dominan dipengaruhi oleh beberapa faktor seperti adanya gangguan pada saluran cerna anak (anak tidak dapat mengunyah ataupun menelan makanan yang disajikan) dan ketidaksukaan anak terhadap jenis makanan tertentu.

\section{KESIMPULAN}

Hasil analisis korelasi Product Moment Pearson didapat nilai $\mathrm{r}=0,107$ dengan $\rho$ value $=0,419(\alpha 0,05)$ berarti tidak signifikan, maka Ho diterima dan Ha ditolak. Jadi, tidak ada hubungan pola asuh Ibu dengan perilaku sulit makan anak pada anak usia prasekolah di RW. 002 Kelurahan Sidomulyo Kota Bengkulu. 


\section{SARAN}

Diharapkan kepada petugas kesehatan, khususnya perawat agar dapat memberikan informasi dan masukan bagi ibu yang memiliki anak usia prasekolah tentang perilaku sulit makan untuk mencegah dan mengatasi perilaku sulit makan pada anak.

\section{DAFTAR PUSTAKA}

Hariani. (2015). Faktor-faktor yang Berhubungan dengan Kesulitan Makan Pada Anak Usia 3-5 Tahun di TK Gowata Desa Taeng Kec. Pallangga Kab. Gowa. Jurnal Ilmiah Kesehatan Diagnosis, 5(6), 661-666.

Judarwanto, W. (2011). Mengatasi Kesulitan Makan Pada Anak. Jakarta: Puspa Swara.

Karaki, K. B., Kundre, R., \& Karundeng, M. (2016). Hubungan Pola Asuh Ibu dengan Perilaku Sulit Makan pada Anak Usia Prasekolah (3-5 Tahun) di Taman Kanak-Kanak Desa Palelon Kec. Modoinding Minahasa Selatan. Jurnal Keperawatan, 4(1), 1-7

Kemenkes RI. Profil Kesehatan Indonesia Tahun 2014. Jakarta: Kemenkes RI; 2015.

Khomsan, A. (2009). Pangan Dan Gizi Untuk Kesehatan. Jakarta: Raja Grafindo Persada.

Padila, P., Andari, F. N., Harsismanto, J., \& Andri, J. (2019). Tumbuh Kembang Anak Usia Toddler Berbasis Research. Lubuklinggau: Asra.

Prasetyo, Y. B. (2011). Analisis Faktor Keluarga, Sosial dan Psikologi Terhadap Gangguan Sulit Makan Pada Anak Dalam Konteks Keperawatan Komunitas di Desa Taman Harjo Kecamatan Singosari Kabupaten Malang Jawa Timur. Tesis. Tidak dipublikasikan.

Saragih, FS. (2011). Pengaruh Penyuluhan Terhadap
Pengetahuan dan Sikap Ibu tentang Makanan Sehat dan Gizi Seimbang di Desa Merek Jaya Kecamatan Raya Kabupaten Simalungun. Skripsi. Fakultas Kesehatan Masyarakat. Universitas Sumatra Utara: Medan.

Septiari, B. B. (2012). Mencetak Balita Cerdas dan Pola Asuh Orang Tua. Yogyakarta: Nuha Medika.

Siswono. (2011). Jaringan Informasi Pangan dan Gizi, volume XIV. Ditjen Bina Gizi Masyarakat. Jakarta.

Soetjiningsih. (2013). Tumbuh Kembang Anak. Bali: EGC.

Waugh, RB., Markham L., Kreipe RE, Walsh BT. (2010). Feeding and Eating Disorder Childhood. International Journal of Eating Disorder, 43(2), 98-111. Diperoleh tanggal 6 Januari 2015 dari http://www.ncbi.nlm.nih.gov/ pubmed/200063374

Zaviera. (2012). Mengenali dan Memahami Tumbuh Kembang. Jogjakarta: Kata Hati. 